University of Montana

ScholarWorks at University of Montana

$5-2004$

\title{
Rapid Evolution of an Invasive Plant
}

John L. Maron

University of Montana - Missoula, john.maron@mso.umt.edu

Montserrat Vilà

Riccardo Bommarco

Sarah Elmendorf

Paul Beardsley

Follow this and additional works at: https://scholarworks.umt.edu/biosci_pubs

Part of the Biology Commons

Let us know how access to this document benefits you.

\section{Recommended Citation}

Maron, John L.; Vilà, Montserrat; Bommarco, Riccardo; Elmendorf, Sarah; and Beardsley, Paul, "Rapid Evolution of an Invasive Plant" (2004). Biological Sciences Faculty Publications. 235.

https://scholarworks.umt.edu/biosci_pubs/235

This Article is brought to you for free and open access by the Biological Sciences at ScholarWorks at University of Montana. It has been accepted for inclusion in Biological Sciences Faculty Publications by an authorized administrator of ScholarWorks at University of Montana. For more information, please contact

scholarworks@mso.umt.edu. 


\title{
RAPID EVOLUTION OF AN INVASIVE PLANT
}

\author{
John L. Maron, ${ }^{1,6}$ Montserrat Vilà, ${ }^{2}$ Riccardo Bommarco, ${ }^{3}$ Sarah Elmendorf, ${ }^{4}$ \\ AND PAUL BEARDSLEY 5 \\ ${ }^{1}$ Division of Biological Sciences, University of Montana, Missoula, Montana 59812 USA \\ ${ }^{2}$ Centre de Recerca Ecològica i Aplicacions Forestals, Universitat Autònoma de Barcelona, 08193 Bellaterra, Spain \\ ${ }^{3}$ Department of Ecology and Crop Production Science, Swedish University of Agricultural Sciences, Box 7043, \\ SE-750 07 Uppsala, Sweden \\ ${ }^{4}$ Environmental Science and Policy Department, University of California, Davis, California 95616 USA \\ ${ }^{5}$ Department of Botany, University of Washington, Seattle, Washington 98195 USA
}

\begin{abstract}
Exotic plants often face different conditions from those experienced where they are native. The general issue of how exotics respond to unfamiliar environments within their new range is not well understood. Phenotypic plasticity has historically been seen as the primary mechanism enabling exotics to colonize large, environmentally diverse areas. However, new work indicates that exotics can evolve quickly, suggesting that contemporary evolution may be more important in invasion ecology than previously appreciated. To determine the influence of contemporary evolution, phenotypic plasticity, and founder effects in affecting phenotypic variation among introduced plants, we compared the size, fecundity, and leaf area of St. John's wort (Hypericum perforatum) collected from native European and introduced western and central North American populations in common gardens in Washington, California, Spain, and Sweden. We also determined genetic relationships among these plants by examining variation in amplified fragment length polymorphism (AFLP) markers.

There was substantial genetic variation among introduced populations and evidence for multiple introductions of $H$. perforatum into North America. Across common gardens introduced plants were neither universally larger nor more fecund than natives. However, within common gardens, both introduced and native populations exhibited significant latitudinally based clines in size and fecundity. Clines among introduced populations broadly converged with those among native populations. Introduced and native plants originating from northern latitudes generally outperformed those originating from southern latitudes when grown in northern latitude gardens of Washington and Sweden. Conversely, plants from southern latitudes performed best in southern gardens in Spain and California. Clinal patterns in leaf area, however, did not change between gardens; European and central North American plants from northern latitudes had larger leaves than plants from southern latitudes within these regions in both Washington and California, the two gardens where this trait was measured. Introduced plants did not always occur at similar latitudes as their most closely related native progenitor, indicating that pre-adaptation (i.e., climate matching) is unlikely to be the sole explanation for clinal patterns among introduced populations. Instead, results suggest that introduced plants are evolving adaptations to broad-scale environmental conditions in their introduced range.
\end{abstract}

Key words: amplified fragment length polymorphisms (AFLPs); EICA hypothesis; founder effects; Hypericum perforatum; introduced plants; latitudinal clines; molecular genetic variation; population differentiation; rapid evolution; St. John's wort.

\section{INTRODUCTION}

Exotic species can often be larger or more fecund in their introduced range than in their native range (Elton 1958, Crawley 1987, Fowler et al. 1996, Rees and Paynter 1997, Buckley et al. 2003, Grosholz and Ruiz 2003). Why this may be so has remained elusive, despite growing interest in this topic. Phenotypic plasticity has traditionally been seen as a key to colonization success and a likely explanation for why indi-

Manuscript received 10 March 2003; revised 7 July 2003; accepted 1 August 2003; final version received 10 September 2003. Corresponding Editor: S. Lavorel.

${ }^{6}$ E-mail: john.maron@mso.umt.edu viduals appear so robust in recipient communities (Marshall and Jain 1968, Rice and Mack 1991, Sultan and Bazzaz 1993, Williams et al. 1995, Kaufman and Smouse 2001, Novak and Mack 2001, Sexton et al. 2002, Parker et al. 2003). Species introduced to new regions may face a more benign environment from whence they came, either because they escape from their native competitors or specialist herbivores and pathogens, or because they occur in locations that possess physical conditions that are more suitable for prolonged growth (Elton 1958, Gillett 1962, Crawley 1987). Introduced plants may respond flexibly to a more benign biotic or physical environment by growing more vigorously or devoting more resources to repro- 
duction. Understanding the magnitude of these changes in phenotype is important because size and fecundity can greatly influence interactions between natives and exotics and thereby critically determine colonization success.

Although phenotypic plasticity can be an important mechanism allowing exotics to succeed in recipient communities, so too may evolution. Early classic studies on plants highlighted the fact that exotics often have substantial evolutionary potential (Baker and Stebbins 1965, Baker 1974, Jain and Martins 1979, Brown and Marshall 1981). Yet, the idea that evolution could be an important force in the ecology of invasions has been mostly neglected in the ecological literature on exotics. Only recently have ecologists recognized that species introduced to new environments can evolve rapidly (Losos et al. 1997, Reznick et al. 1997, Weber and Schmid 1998, Yom-Tov et al. 1999, Huey et al. 2000, Bone and Farres 2001, Lee 2002) and that rapid genetically based adaptation to novel environments might be more important in the ecology of invasions than previously thought.

Two distinct but not mutually exclusive classes of selection pressures might drive contemporary evolution within exotic plant populations. First, liberation of exotic plants from their natural enemies might lead to the evolution of increased plant size or fecundity. Blossey and Nötzold (1995) proposed that introduced plants that are no longer attacked by specialist enemies should lose costly herbivore defense and re-allocate resources previously spent on defense to traits that enhance competitive ability, such as increased size or fecundity. The evolution of increased competitive ability (EICA) hypothesis predicts that introduced plants should universally be larger or more fecund than their native conspecifics; if true, it implies that rapid evolutionary change may play a key role in invasion success.

Tests of the EICA hypothesis have been inconclusive. Both Siemann and Rogers (2001) and Blossey and Nötzold (1995) found introduced individuals were larger or more fecund than native individuals of Chinese tallow trees (Sapium sebiferum) and purple loosestrife (Lythrum salicaria), respectively. Leger and Rice (2003) found that introduced California poppies (Eschscholzia californica) from Chile were larger and more fecund than native Californian conspecifics in common gardens, but only in the absence of competition. On the other hand, Willis et al. (2000) grew four species of plants collected from their native European and introduced ranges in a common garden in Britain and found no evidence that introduced plants had evolved increased size. Thébold and Simberloff (2001) similarly found no consistent evidence (based on data in accounts of the flora of Europe and the United States) that introduced genotypes were larger than their native counterparts.
Second, geographic gradients in abiotic conditions across the introduced range could impose divergent selection and promote genetically based differentiation among introduced populations. A classic manifestation of this would be the evolution of geographic clines, as is often found among native populations occurring across altitudinal or elevational gradients (Turreson 1930, Clausen et al. 1940, Neuffer and Hurka 1986, Lacey 1988, Galen et al. 1991, Winn and Gross 1993, Jonas and Geber 1999). Yet, whether introduced plant populations rapidly evolve clines in response to environmental conditions across their introduced range is seldom studied (but see Neuffer 1990, Weber and Schmid 1998, Neuffer and Hurka 1999). Furthermore, whether clines in traits among introduced plant populations broadly converge on those expressed among native conspecifics occurring over similar latitudinal or elevation gradients is unknown. There is certainly precedence for such clinal convergence. Introduced populations of Drosophila subobscura have rapidly evolved clinal variation in wing shape that converges on that found for native fruit flies occurring across a similar latitudinal gradient (Huey et al. 2000).

Here, by means of common garden experiments in the native and introduced range and genetic analyses of plants, we explore whether the widespread exotic plant, St. John's wort (Hypericum perforatum), has undergone contemporary adaptive evolution (sensu Stockwell et al. 2003) in its introduced range. Specifically, we ask: (1) whether introduced St. John's wort populations have evolved latitudinally based clines in size, fecundity, leaf area, or survival, as might be expected if abiotic conditions drive adaptation, (2) whether native populations of St. John's wort also exhibit clinal variation in traits in common gardens, and if so, how clines in the native and introduced range compare, and (3) whether introduced $H$. perforatum has evolved larger size or fecundity in response to an enemy-free environment, as predicted by the EICA hypothesis. Because of St. John's wort's history of introduction, spread, and subsequent control, our study provides a unique test of the EICA hypothesis. In western North America, St. John's wort has been exposed to biocontrol for over 50 years, whereas introduced plants in central North America have either never been exposed to biocontrol or in a few localities have had a much more recent exposure to biocontrol (Julien and Griffiths 1998). Although many factors besides exposure to biocontrol (for example, climate) potentially contribute toward selecting for particular traits in western and central North American populations, if the EICA hypothesis is correct, plants liberated from specialist herbivores that reside in central North America should tend to be larger or more fecund than plants from European populations when grown in common gardens. Additionally, EICA predicts that plants from western North American populations should be intermediary in 
size between central North American and European plants as a result of their biocontrol history.

While comparison of traits in common gardens provides insight into whether there has been genetically based differentiation among introduced populations, evidence for clinal differentiation does not, in itself, necessarily imply contemporary evolution. Multiple introductions from a genetically diverse source pool could produce a good match between the set of conditions a genotype is adapted to and the conditions it experiences where introduced (Neuffer and Hurka 1999). If this is the case, no evolution has occurred; rather, introduced genotypes only persist in areas where they are pre-adapted. Alternatively, clinal patterns in traits within common gardens could result from adaptive evolution within the introduced range. This could occur either as a result of adaptive radiation from a limited number of founding genotypes, or from multiple introductions that provide sufficient genetic variability on which selection can act. To differentiate between these alternatives, we used amplified fragment length polymorphism (AFLP) markers to examine genetic relationships between native and introduced plants, and thereby infer the invasion history of St. John's wort.

\section{Methods}

\section{St. John's wort natural history}

St. John's wort is a short-lived rhizomatous perennial native to Europe, North Africa, and Asia. These plants inhabit old fields, overgrazed, or otherwise disturbed grasslands, forest clearings, gravel river banks, and road sides. Individuals grow as prostrate mats in winter, then bolt, flower, and set seed in summer. After seed set, plants senesce aboveground until winter rains initiate new procumbent growth.

As an introduced weed, St. John's wort is widely distributed. It has been introduced into Australia, New Zealand, South Africa, and North and South America. In the United States, St. John's wort was first found in 1793, in Lancaster, Pennsylvania. St. John's wort was found in some portions of the Midwest in the mid1800s (Sampson and Parker 1930, Voss 1985) and on the West Coast, in Oregon, between 1840 and 1850. By the early 1900s, St. John's wort was found in California (Campbell and Delfosse 1984, Voss 1985). Biological control of St. John's wort in western North America was first initiated in 1945, with the introduction of a chrysomelid beetle, Chrysolina quadrigemina (Huffaker and Holloway 1949, Holloway and Huffaker 1951). Beetles established and killed many plants; within five years of introduction in California, H. perforatum was reduced to $<1 \%$ of its former abundance (Holloway 1957). Whether biocontrol in the West is currently as efficacious as it was initially is not well documented. In central North America, St. John's wort never reached the densities observed in the West, likely because cropland habitat is not ideal for St. John's wort. Biocontrol introductions in eastern North America occurred much later than in western North America (in 1969 vs. 1945); biocontrol beetles have only recently spread to several eastern states and Minnesota (Harris and Maw 1984, Fields et al. 1988, Hoebeke 1993, Julien and Griffiths 1998). Thus, throughout central North America, St. John's wort has either never been exposed to biocontrol or plants have had a much more limited history of herbivore exposure than have plants in western North America. Censuses of multiple introduced populations indicate that in the absence of biocontrol agents, St. John's wort receives minimal herbivore pressure by native generalists (J. L. Maron and M. Vilà, unpublished data). Plants we out planted into common gardens received little or no herbivore damage.

\section{Seed collection}

In late summer 1998 and 1999, we collected mature seed capsules of $H$. perforatum from three distinct regions: Europe, western North America, and central North America (N.A.). We collected seeds from 18 native populations (17 in Europe plus one population in Kyrgyzstan; for simplicity we collectively refer to all 18 populations as European), 18 introduced western North American populations, and 14 introduced central North American populations (see Appendix for additional information on seed source populations and collection methods). Seed capsules were collected from 10-14 haphazardly chosen individuals per population, except European populations 5, 10, 12, and 13 (see Appendix for location of populations), where we collected a pooled sample of capsules from $>10$ individuals.

\section{Common garden experiments}

We established two large common gardens in Snohomish, Washington, USA, and at the Mas Badia Experimental Field Station (IRTA) near Girona, Spain, in spring 2000. In 2001, we established two additional smaller common gardens, on the Wantrup Preserve in Pope Valley, California, USA, and near Sörby on the island of Öland, Sweden (see Table 1 for information on common garden sites, dates of transplant, number of individuals, and populations used in each garden, etc.) In each garden, individuals from each population were maternal sibs of those planted in other gardens. Since St. John's wort produces upwards of $90 \%$ of its seed apomictically, maternal sibs planted in all gardens were likely clones (Robson 1968, Arnholdt-Schmitt 2000). To ensure that transplants were not overtopped by surrounding grasses, we periodically mowed between plots and/or hand-clipped grasses immediately surrounding experimental plants. St. John's wort occurred naturally near each garden site. Plot spacing and the layout of plants among gardens differed due to space and other logistical considerations. The com- 
TABLE 1. Comparison of the four common garden sites with respect to physical conditions and timing of plant propagation, outplanting, and measurement.

\begin{tabular}{|c|c|c|c|c|c|c|}
\hline Location & Latitude & $\begin{array}{l}\text { Mean annual } \\
\text { precipitation } \\
\text { (cm) }\end{array}$ & $\begin{array}{c}\text { Mean daily } \\
\text { maximum } \\
\text { temperature }\left({ }^{\circ} \mathrm{C}\right)\end{array}$ & $\begin{array}{c}\text { Mean daily } \\
\text { minimum } \\
\text { temperature }\left({ }^{\circ} \mathrm{C}\right)\end{array}$ & $\begin{array}{l}\text { Dates plants } \\
\text { propagated in } \\
\text { greenhouse }\end{array}$ & $\begin{array}{l}\text { Individuals } \\
\text { used per } \\
\text { population }\end{array}$ \\
\hline Snohomish, Washington & $47^{\circ} 52^{\prime} \mathrm{N}$ & 123 & 22.8 & 0.7 & March 2000 & 10 \\
\hline Pope Valley, California & $38^{\circ} 36^{\prime} \mathrm{N}$ & 106 & 30.8 & 2.9 & January 2001 & 9 \\
\hline Sörby, Sweden & $56^{\circ} 50^{\prime} \mathrm{N}$ & 42 & 27.6 & -7.7 & April 2001 & 9 \\
\hline Girona, Spain & $42^{\circ} 19^{\prime} \mathrm{N}$ & 62 & 31.0 & 10.0 & March 2000 & 14 \\
\hline
\end{tabular}

Note: Plants were propagated in greenhouses at the University of Washington (for Washington and California), the University of Barcelona (for Spain), and the Swedish University of Agricultural Sciences (for Sweden).

petitive environment across gardens was roughly similar.

Washington common garden.-We established 10 replicate, $8.5 \times 12 \mathrm{~m}$ blocks composed of six $1.5 \times$ $12 \mathrm{~m}$ plots separated by $2 \mathrm{~m}$. Plants in three of these plots were exposed to herbivory by Chrysolina quadrigemina as part of a separate experiment and not discussed here. One individual from each population within a given region was randomly assigned to the same plot within blocks. Thus, each plot within a block contained plants from a different region. Across blocks, plots contained a unique individual from each population. Plots consisted of two rows of nine individuals (spaced $1.5 \mathrm{~m}$ apart) from each of 18 populations. Since we only collected seed from 14 central North American populations, we added four randomly selected replicate plants to each central North American plot to maintain plant density at 18 in each plot. No data were collected from these replicate plants.

In September 2000, 2001, and 2002, we estimated plant fecundity: in 2000 by clipping and counting the seed capsules on each plant (n), and in 2001 and 2002 by harvesting, drying, and weighing seed capsules since plants had too many capsules to count individually. On a subset of plants in 2001 and 2002, we both counted and weighed seed capsules to determine the relationship between capsule mass $(M)$ and capsule number $(N)$. We used these regressions (2001 regression, $N=44.45 M-3.71, R^{2}=0.93, P<0.0001, n$ $=43 ; 2002$ regression, $N=43.5 M+22.2, R^{2}=0.97$, $P<0.0001, n=85)$ to convert capsule mass into capsule number each year.

We censused all plants in July 2001 and 2002. We estimated plant size by treating each plant as a cylinder and calculating cylindrical volume $(V)$. To do this, we measured the width of each plant in perpendicular directions ( $W 1$ and $W 2)$ and then measured the height of the tallest stem $(H)$; thus, $V=\pi[(W 1+W 2) / 4]^{2} \times H$.

In July 2002, we randomly chose one of two opposite leaves at the sixth node on the tallest stem on each plant and measured the length and maximum width of this leaf on all plants. These leaves were similar in size to those sampled at other nodes on the same plant (Pearson $r=0.74)$. We calculated the relationship between leaf length $(L) \times$ maximum width $(W)$ and leaf area
(LA) by measuring leaf length and width of greenhouse-grown plants and then estimating their area by using image analysis performed on a Macintosh computer using public-domain NIH image program version 1.62 (developed at the U.S. National Institute of Health; available online $)^{7}$ to analyze digitally scanned images of these leaves when dried and flattened. We then applied the equation LA $=[(W \times L) \times 0.785]+0.002$ $\left(R^{2}=0.99, n=500\right)$ to field-measured leaves to convert leaf size to leaf area.

California common garden.-We established nine replicate blocks composed of six plots (three of which were used for a separate experiment and not discussed here). Plants from a given region were all assigned to the same randomly chosen plot within blocks. Plots consisted of two rows of six plants from the same region but from different populations within that region, except for central North American plots that contained two rows of five plants. Plants within plots were separated by $1 \mathrm{~m}$, plots were separated from each other by $1.5 \mathrm{~m}$, and blocks were separated from each other by $2 \mathrm{~m}$.

In April 2002, we censused all plants and estimated plant size, as described in Methods: Common garden experiments, Washington common garden. We also measured the length and width of one randomly chosen leaf at the fourth node on the tallest stem of each plant. We then converted leaf size to leaf area, as described above. We censused all plants and estimated plant fecundity in late July 2001. Only six plants produced seed capsules, and these plants produced no more than a few capsules each. In mid-July 2002, we again censused plants and estimated fecundity, as we did in Washington in 2002.

Spain common garden.-We randomly assigned one individual from each population within a region to one of $144 \times 4 \mathrm{~m}$ plots (42 plots total). Individuals within plots were separated by $1 \mathrm{~m}$, and plots were separated by $2.5 \mathrm{~m}$.

In September 2000, we censused all plants and estimated fecundity by counting seed capsules on plants. In April 2001, after plants had been in the field for 11 months, we censused and measured all plants. At this

${ }^{7}$ URL: 〈http://rsb.info.nih.gov/nih-image/〉 
TABle 1. Extended.

\begin{tabular}{|c|c|c|c|c|c|c|}
\hline \multicolumn{3}{|c|}{ Populations used per region } & \multirow[b]{2}{*}{$\begin{array}{l}\text { Field preparation } \\
\text { prior to transplant }\end{array}$} & \multirow[b]{2}{*}{$\begin{array}{l}\text { Transplant } \\
\text { date }\end{array}$} & \multirow[b]{2}{*}{$\begin{array}{c}\text { Dates plant } \\
\text { size measured }\end{array}$} & \multirow[b]{2}{*}{$\begin{array}{l}\text { Dates fecundity } \\
\text { estimated }\end{array}$} \\
\hline Europe & $\begin{array}{l}\text { Western } \\
\text { North } \\
\text { America }\end{array}$ & $\begin{array}{c}\text { Central } \\
\text { North } \\
\text { America }\end{array}$ & & & & \\
\hline 18 & 18 & 14 & mowed and tilled & April 2000 & July 2001, 2002 & September 2000, 2001, 2002 \\
\hline 12 & 12 & 10 & mowed and tilled & March 2001 & April 2002 & July 2001,2002 \\
\hline 10 & 9 & 9 & mowed & April 2001 & June 2002 & September 2002 \\
\hline 16 & 16 & 13 & mowed and tilled & June 2000 & April 2001 & September 2000 , October 2001 \\
\hline
\end{tabular}

time, most individuals had not yet bolted and grew as prostrate mats that were roughly circular. We estimated mat area (MA) by measuring the diameter of each mat in two perpendicular directions ( $L 1$ and $L 2)$ and converting these values to area (where MA $=((L 1+L 2)$ $4) 2 \times \pi)$. Mat area prior to bolting is correlated to plant size after bolting (Pearson $r=0.65, P<0.0001$ ). In late October 2001, we again censused all plants and estimated fecundity by harvesting, drying, and weighing seed capsules. We converted capsule mass into capsule number, as was done for plants grown in Washington in 2001.

Sweden common garden.-We established nine replicate blocks composed of three plots, with each plot containing plants from a single region. Regions were randomly assigned to plots within blocks. Plants were spaced $1.2 \mathrm{~m}$ apart within a plot, plots within blocks were separated by $1.5 \mathrm{~m}$, and blocks were separated from each other by 3-4 $\mathrm{m}$.

In mid-June 2002, we censused all plants and counted the number of shoots on each individual. In midSeptember 2002, we harvested, dried, and weighed seed capsules from each plant, as described in Methods: Common garden experiments, Washington common garden.

\section{Analysis of common garden data}

Within each garden, we determined whether there was significant differentiation in plant size, fecundity, or leaf area based on latitude of population origin. Latitudinally based differentiation within a common garden is classic evidence for a geographic cline, and suggests that plants have adapted to the broad-scale environmental conditions experienced across their home environment (i.e., Europe for native genotypes and North America for introduced genotypes). After statistically controlling for latitude, we explored whether plant size or fecundity varied based on region of population origin, as predicted by the EICA hypothesis. To make these comparisons, in the PROC GLM module within SAS (2001) we performed an ANCOVA with Type I sum of squares, using the following model: response variable $=$ block (except for Spain where plants were not blocked in the field) + latitude of population origin + region of population origin + latitude $\times$ region + population nested within region + error. Block and population nested within region were random factors, region was a fixed factor, and latitude was a covariate. A significant population within region effect indicates that there is population differentiation and that this differentiation is not due to latitude of origin (since variation among populations due to latitude is removed before testing the population with region effect). We used Type I rather than Type III sum of squares because most populations had unique latitudes of origin (Table 1) and there were insufficient degrees of freedom to simultaneously use latitude and population nested with region within a Type III sum of squares model. Response variables in these analyses were plant volume (log-transformed to meet assumptions of the ANCOVA), fecundity (or cumulative fecundity across two and three years for plants grown in Spain and Washington, respectively), and leaf area. We performed Bonferroni post hoc comparisons to examine pairwise differences between regions in mean size or fecundity. To determine how mortality varied based on latitude of population origin, we calculated mortality within each population in a given garden and regressed these population mortality values on latitude of population origin. To examine clinal patterns among introduced plants in isolation, we combined data from western and central N.A. and performed Type I sum of squares ANCOVAs on these data from each garden. We tested for effects of block, latitude, and population, with population and block as random factors and latitude as a covariate.

Finally, we compared the total phenotypic variation among European and western North American populations in each garden, respectively. If there had been a large founder effect and a limited number of genotypes introduced into North America, one might expect phenotypic variation to be greatly reduced among introduced plants compared to natives. To examine this, we calculated the percentage of the total among-population phenotypic variance (based on adjusted population means from the ANCOVA) that was accounted for by native and introduced populations. This test requires roughly balanced numbers of individuals and populations from each region, since differences in sample size can bias variance estimates. In cases where the number of populations sampled was unequal between regions (fecundity in Sweden), we randomly chose an 
equal number of populations from each region. We excluded populations from central N.A. from this analysis since the number of populations sampled was smaller and therefore not comparable to those sampled in $\mathrm{Eu}-$ rope and western N.A. We omitted data from Spain, as high mortality in that garden made for an extremely unbalanced design.

\section{Genetic relations between native and introduced plants}

We used amplified fragment length polymorphisms (AFLPs; Vos et al. 1995, Mueller and Wolfenbarger 1999) to determine genetic relationships between individuals and populations. We clipped leaves from four randomly chosen individuals from each population within the Washington common garden. We extracted total genomic DNA from either fresh, green leaves or leaves that had been frozen using standard procedures (Vos et al. 1995) to produce AFLPs with the following modifications. We digested 400-500 ng of DNA from each plant and ligated adaptors (MseI and $E c o \mathrm{RI}$ ) to the ends in a reaction mixture that contained $5 \mu \mathrm{L} 10 \times \mathrm{RL}$ buffer $(100 \mathrm{mmol} / \mathrm{L}$ Tris-Acetate $\mathrm{pH} 7.6,100 \mathrm{mmol} / \mathrm{L} \mathrm{Mg}$-Acetate, $500 \mathrm{mmol} / \mathrm{L} \mathrm{K}$-Acetate, $50 \mathrm{mmol} / \mathrm{L}$ dithiothreitol), $50 \mathrm{pmol} / \mathrm{L} \mathrm{EcoRI}$ adapter, $50 \mathrm{pmol} / \mathrm{L}$ MseI adapter, $1 \mu \mathrm{mol} / \mathrm{L} 10 \mathrm{mmol} /$ L ATP, 1 unit of T4-DNA ligase, and water to a final volume of $50 \mu \mathrm{L}$. Adapter sequences are the same as those described by Xu et al. (2000). After digestion and ligation, products were diluted 1:4 with water. Digestion/ligation products were amplified with one selective nucleotide using polymerase cahin reaction (PCR) as described in Vos et al. (1995). In the second round of PCR, products were amplified with primers (EcoRI and MseI) labeled using LICOR IRD-800 or LICOR IRD-700 dyes (LI-COR Biosciences, Lincoln, Nebraska, USA). In total, 25 primer pairs were used. Amplification products were visualized using gel electrophoresis on a LI-COR Long ReadIR DNA sequencer. Digital AFLP gel images were scored using AFLPQuantar scoring software (Keygene products B.V., Wageningen, The Netherlands) and also carefully checked by eye to ensure Quantar scoring was accurate. Prior to analysis, we eliminated one individual from populations Spain 1, France 7, Czech 14, Ontario 10, and Michigan 14, because these plants had anomalously low numbers of AFLP fragments. It is likely that methodological problems during sample preparation led to these anomalies.

\section{Analysis of genetic data}

We recorded AFLP band presence or absence for each sample as a binary character. We then analyzed this data matrix in two ways. First, using PAUP* 4.0 (Swofford 1998), we determined relationships among $H$. perforatum individuals and populations using neighbor-joining, a distance-based analysis. Estimates of similarity were calculated using the index of Nei and
Li (1979). We also constructed trees based on parsimony analyses, but these analyses produced qualitatively very similar trees that recovered the same wellsupported clades as those based on neighbor-joining. We arbitrarily picked population 16 from England as the out group because relationships are more easily visualized using rooted trees. Using other out groups yielded qualitatively similar results. Bootstrap values (Felsenstein 1985) for the neighbor-joining tree were calculated using 1000 replicate neighbor-joining searches.

Second, we used analysis of molecular variance (AMOVA; ARLEQUIN software version 2.0, Schneider et al. 2000) to determine how total neutral molecular genetic variation was partitioned between regions and among populations within regions. AMOVA calculates pairwise squared Euclidean distances among AFLP phenotypes, and from these estimates $\Phi$ st, the percentage of total molecular variation that is due to differences among specified hierarchical groups (in our case, between regions of population origin, among populations within regions, and within populations). We first used AMOVA to determine how genetic variation was partitioned between regions and among populations within regions. We then asked, within a given region, how the percent of total molecular genetic variation was partitioned within and among populations. For both of these analyses, we used only data from European and western North American genotypes, since an equal number of populations within these regions were sampled.

\section{RESUlTS}

\section{Genetic relationships between native and introduced plants}

Together, 25 AFLP primer pairs generated 302 polymorphic markers across all samples analyzed. Among 195 individuals, we detected 195 unique AFLP phenotypes. When examined together, individuals from introduced and native populations clustered in several well-supported clades (Fig. 1). The fact that individuals from the introduced range cluster in multiple clades indicates that there have likely been repeated introductions of St. John's wort into North America (Fig. 1). One well-supported clade contains individuals from multiple populations collected in Spain, France, and California, while other well-supported clades contain individuals from populations originating from western and central N.A., as well as individuals from Europe. As was the case for European populations, plants from the same North American populations usually clustered together (see Fig. 1, exceptions: Wisconsin 2-1, Wisconsin 2-3, Michigan 6-10, Ontario 10-5, California 2-4, California 9-7, Oregon 12-8, Oregon 14-14, Oregon 18-10).

Analysis of molecular variance revealed that only $10.42 \%$ of the total molecular genetic variation among European and western North American samples was 
accounted for by region of origin (i.e., Europe vs. western N.A.). The majority of molecular variation (65.6\%) was partitioned among populations within regions, with the remaining molecular variation $(23.91 \%)$ partitioned within populations. For European samples in isolation, $65.67 \%$ of the variation in AFLP haplotypes was due to differences in diversity among populations, whereas $34.33 \%$ of the molecular genetic variation was contained within populations. For western North American genotypes, $78.2 \%$ of the molecular genetic variation was contained among populations, and $21.88 \%$ was contained within populations. Thus, for both native and introduced plants, greater genetic variability was preserved among vs. within populations.

\section{Differences between native and introduced plants in size and fecundity}

There were significant differences in size between native and introduced plants within Spain and Washington common gardens but not within California and Sweden gardens (Table 2). In Spain, plants from European populations were larger $\left(84650 \mathrm{~cm}^{3} \pm 23498\right.$ [unadjusted mean volumes $\pm 1 \mathrm{SE}$ ]) than those from either central $\left(45779 \mathrm{~cm}^{3} \pm 25241\right)$ or western (47 139 $\mathrm{cm}^{3} \pm 22752$ ) North American populations (post hoc comparison, $P<0.05$ ). In Washington, the same was true $\left(191322 \mathrm{~cm}^{3} \pm 40352,169257 \mathrm{~cm}^{3} \pm 27966\right.$, and $122199 \mathrm{~cm}^{3} \pm 26979$ for European, central and western North American plants, respectively; post hoc comparison, $P<0.05$ ).

Cumulatively, western North American plants produced more seed capsules over three years (unadjusted mean $=2748 \pm 237)$ than did European $(2368 \pm 266)$ and central North American $(2430 \pm 160)$ plants in Washington (Table 3; post hoc comparison, $P<0.05$ ). In Sweden, western North American plants also produced more seed capsules (unadjusted mean $=468 \pm$ 42) than did central North American $(453 \pm 42)$ or European $(405 \pm 40)$ plants (post hoc comparison, $P$ $<0.05)$. However, in California, European plants produced more seed capsules (unadjusted mean $=783 \pm$ 250) than did either central or western North American individuals (unadjusted means $=115 \pm 54$ and $683 \pm$ 225 for central and western North American populations, respectively; post-hoc comparison, $P<0.05$; Table 3). In Spain, there was no significant difference in fecundity based on region of origin (Table 3). Thus, in contrast to the prediction of the EICA hypothesis, introduced plants were neither consistently larger nor more fecund than natives across all gardens.

\section{Clinal variation}

Plant size.-St. John's wort from diverse native European and introduced North American populations exhibited significant latitudinally based clines in size in California, Sweden, and Washington, and marginally significant clines in size in Spain (Figs. 2 and 3, Table 2). In relatively northerly common gardens in Sweden and Washington, plants from populations originating at northern latitudes grew larger than plants from southern latitudes (Fig. 2). In more southern latitude common gardens in California and Spain, the opposite pattern prevailed; plants originating from southern latitudes were larger than plants originating from northern latitudes (Fig. 3). When introduced North American plants were analyzed separately, there were significant clinal patterns in size in common gardens in California $\left(F_{1,20}=8.5, P<0.008\right)$, Sweden $\left(F_{1,22}=10.1, P<\right.$ $0.005)$, and Washington $\left(F_{1,30}=16.4, P<0.003\right)$ and a marginally significant cline in Spain $\left(F_{1,27}=3.7, P\right.$ $=0.07)$.

Plant fecundity.-Both introduced and native plants produced abundant seed capsules in their first summer in Washington and Spain. In Sweden and California, plants did not flower and set seed until their second summer (with the exception of six individuals in California that each produced fewer than 10 seed capsules). Among all populations, fecundity varied in a strong clinal pattern in all common gardens except Spain, where there was a marginally significant effect of latitude on fecundity (Figs. 4 and 5, Table 3). As was the case for size, plants from northern latitudes outperformed plants from southern latitudes in northern common gardens in Sweden and Washington (Fig. 4), but performed less well than plants from southern latitudes when grown in southern common gardens in California and Spain (Fig. 5).

In Washington, clinal patterns in fecundity switched dramatically between years. Mean cumulative fecundity (across years one and two) among populations was negatively related to latitude of population origin (Fig. 4). Plants from southern latitudes performed better than those from northern latitudes despite the fact that the Washington garden was at a more northerly latitude. However, in their third year (2002), fecundity was higher for plants from northern latitudes than those from southern sites (Fig. 4). This clinal shift coincided with large differences between years in rainfall. The winter of year two (2001) was unusually dry (mean cumulative rainfall from January to May $=38.7 \mathrm{~cm}$ ) and significantly drier than the 20-year rainfall average for this period $(57.4 \mathrm{~cm}$ [one-sample $t$ test, $t=7.4, P<$ 0.0001]). This created conditions more similar to what typically would be found at a more southerly locale. Since seed capsule production in year two made up the lion's share of the cumulative two-year total, the environmental conditions during year two had a predominant impact on cumulative fecundity in the first two years. However, in year three (2002), cumulative rainfall during January-May was $58.5 \mathrm{~cm}$, not significantly different from the long-term average (one-sample $t$ test, $t=0.05, P=0.95)$.

Introduced populations, when analyzed alone, exhibited significant clines in fecundity in California $\left(F_{1,20}=11.3, P<0.003\right)$, Sweden $\left(F_{1,17}=11.3, P<\right.$ 0.003 ), and Washington (cumulative fecundity across 


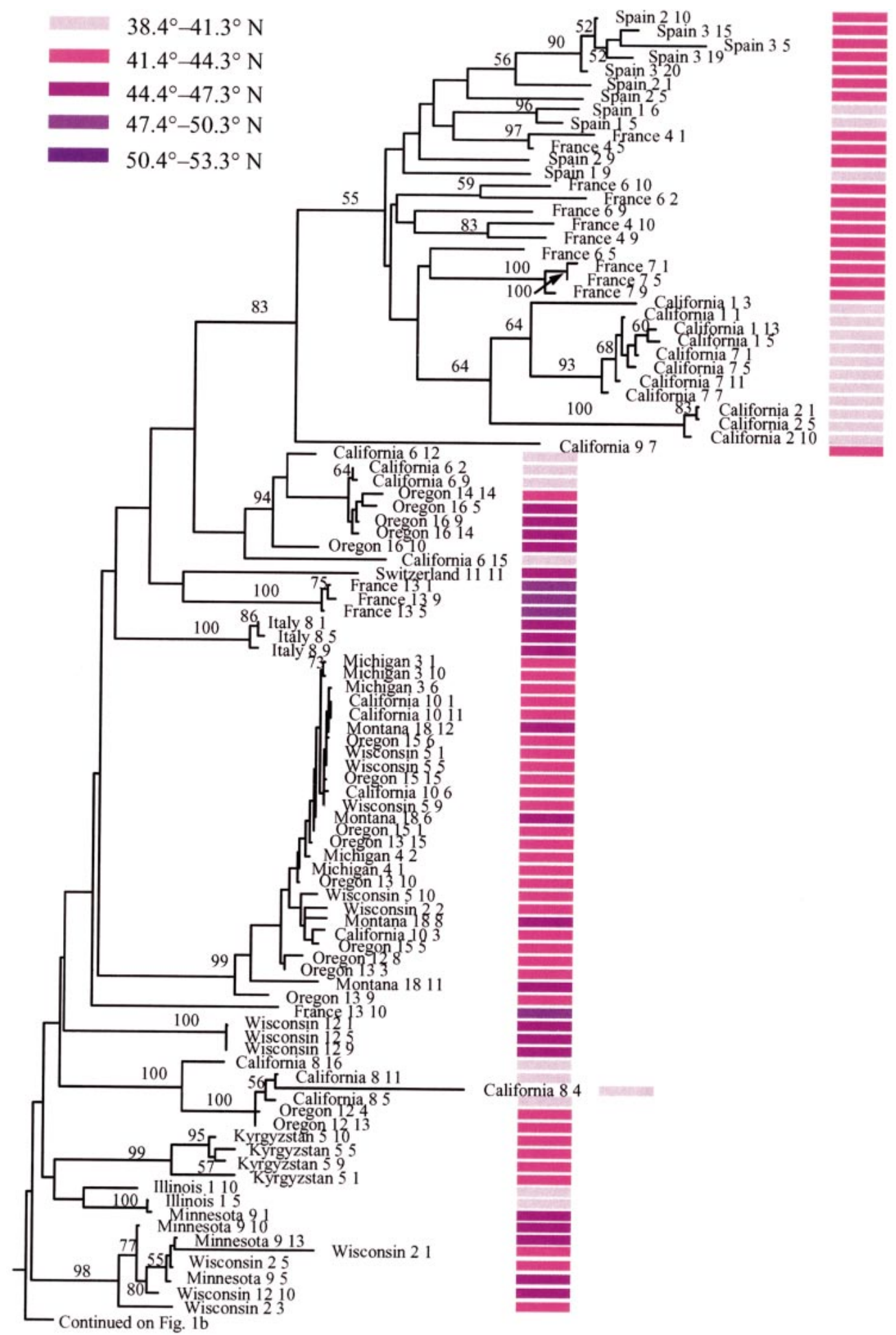

FIG. 1. Neighbor-joining tree of 195 Hypericum perforatum genotypes from 50 populations across Europe and North America. The first number after the country or state name is the population number, followed by the individual number (see the Appendix for the specific geographic location that corresponds to each population number). Numbers at nodes represent confidence levels for clades with $>49 \%$ bootstrap support based on 1000 replicates. At right, colored bars represent latitudinal ranges encompassing the latitude at which each individual was collected. Please note that the bottom of Fig. 1a (left) continues at the top of Fig. 1b (right). 


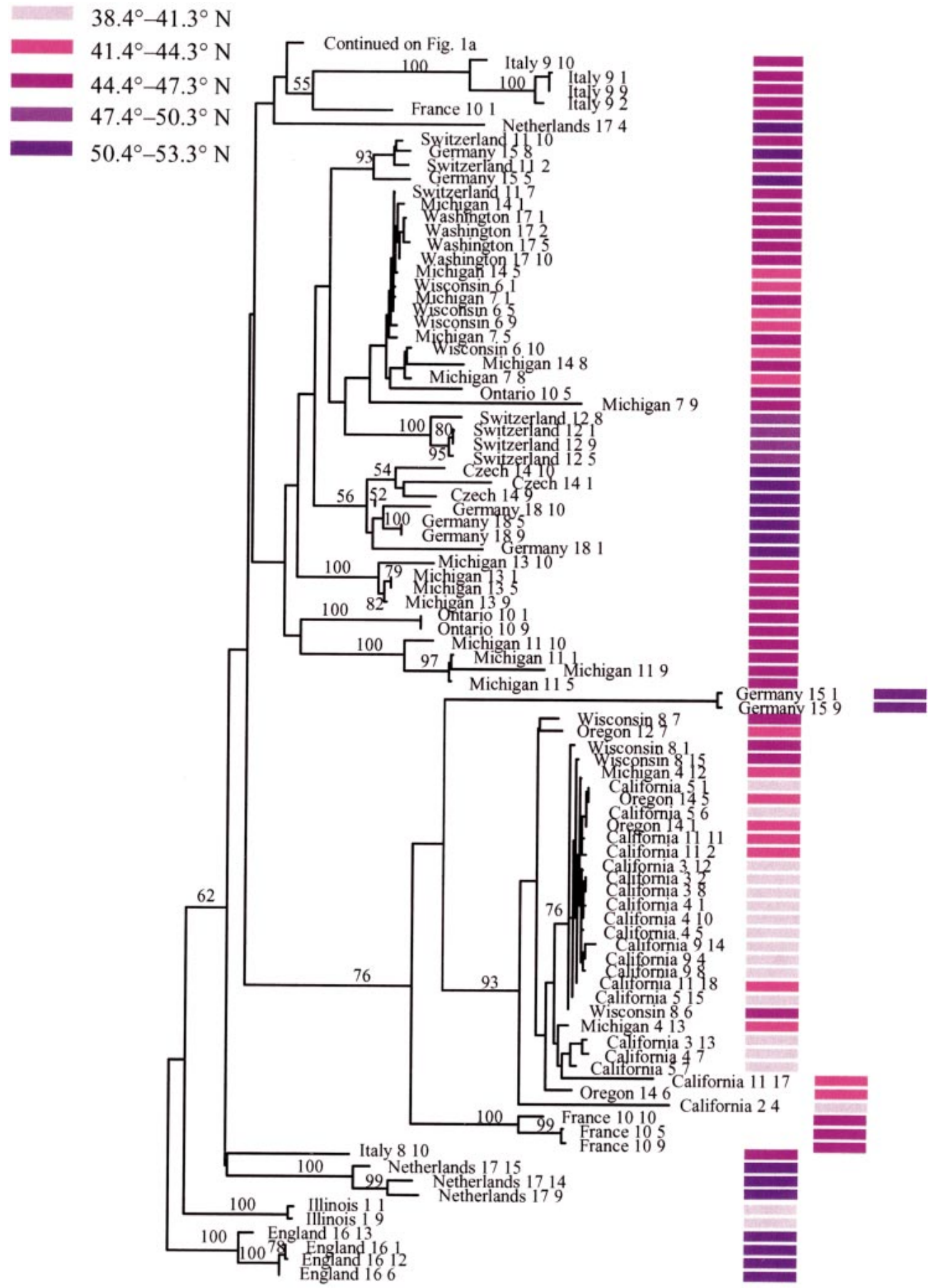

FIG. 1. Continued.

two years, $\left.F_{1,30}=9.7, P<0.004\right)$, but not in Spain $(P$ $=0.27$ ). Because of the switch in plant fecundity between the first two years (2000 and 2001) and the third (2002), there was no significant clinal pattern in cumulatively three-year fecundity in Washington $(P=$ 0.88).
Leaf size.-Plants exhibited significant clinal variation in leaf area in Washington and California (Table 4). Unlike for size and fecundity, however, populations did not change rank between the northern and southern common gardens. Instead, individuals from northern latitude populations had larger leaves than those from 
TABLE 2. Results from ANCOVAs testing for the effect of block (except in Spain), latitude of population origin, region of population origin, latitude $\times$ region interaction, and population nested within region on plant size in California (CA), Sweden (SW), Spain (SP), and Washington (in the third year [2002]; WA).

\begin{tabular}{|c|c|c|c|c|c|c|c|c|}
\hline \multirow[b]{2}{*}{ Source } & \multicolumn{4}{|c|}{$\mathrm{CA}$} & \multicolumn{4}{|c|}{ SW } \\
\hline & df & MS & $F$ & $P$ & df & MS & $F$ & $P$ \\
\hline Block & 8 & 8.4 & 5.5 & 0.0001 & 8 & 112.9 & 2.1 & 0.04 \\
\hline Latitude & 1 & 6.4 & 12.7 & 0.001 & 1 & 434 & 37.2 & 0.0001 \\
\hline Region & 2 & 0.8 & 0.8 & 0.47 & 2 & 42.1 & 1.9 & 0.18 \\
\hline Latitude $\times$ region & 2 & 0.2 & 0.2 & 0.81 & 2 & 9.5 & 0.4 & 0.64 \\
\hline Population(region) & 28 & 14.1 & 2.7 & 0.0001 & 23 & 258.8 & 1.7 & 0.03 \\
\hline Error & 252 & 47.7 & & & 186 & 1262 & & \\
\hline
\end{tabular}

southern latitude populations in both gardens (Fig. 6) When introduced plants were analyzed in isolation, we found no significant effect of latitude on leaf area, in either the Washington $\left(F_{1,30}=0.4, P=0.53\right)$ or California gardens $\left(F_{1,20}=1.9, P=0.19\right)$.

\section{Other components of variation in size and fecundity among introduced and native plants}

In all gardens, there were significant differences in size and fecundity among individuals from different populations, even after variation due to latitude of origin was removed (Tables 2 and 3). This was true not only for introduced and native populations combined, but also in analyses using only introduced plants $(P<$ 0.02 in all gardens). Thus, introduced plants from divergent populations were genetically differentiated, with this differentiation based both on latitude as well as other unknown factors that varied between populations.

Introduced plants from western North American populations exhibited almost as much, or in some cases even greater, phenotypic variation in size and fecundity as did natives. For example, in Washington, western North American populations accounted for almost $61 \%$ of the total among population variation in size. In Sweden, introduced populations accounted for over $71 \%$ of the total among population variation in fecundity (Table 5). For size in California and Sweden, and fecundity in California and Washington, total phenotypic variation was relatively equally partitioned among introduced and native populations (Table 5).

\section{Patterns of mortality}

Across all populations, mortality in common gardens in California, Washington, and Sweden was remarkably low, despite the fact that common gardens contained plants originating from widely disparate localities. In California, only 6\% (out of 300) of all plants died after 16 months in the field. In Washington, after 29 months in the field, $4.6 \%$ (out of 500) of plants died (excluding an entire block of 50 plants from all regions that were overgrown by grasses and killed during late spring of their second year). In Sweden, $9.7 \%$ (out of 248) of plants died in the 14 months they were in the field. In all of these gardens, the percentage mortality of indi- viduals within each population was significantly correlated with latitude of population origin $\left(R^{2}=0.18\right.$, $F_{1,32}=7.1, P<0.01$ for California, $R^{2}=0.16, F_{1,26}$ $=4.8, P<0.037$ for Sweden, and $R^{2}=0.08, F_{1,48}=$ $4.3, P<0.05$ for Washington). For these three gardens, mortality was always lowest within populations that originated from latitudes closest to that of the common garden and highest within populations that originated at more distant latitudes from that of the common garden.

In Spain, mortality was substantially higher than in the other gardens. Fifty-three percent of all individuals (of 630) initially planted in the common garden died throughout the 16 months of the study. Mortality was high in part due to pathogen attack. Plants were attacked in their second spring by three conspicuous fungal pathogens (Colletotrichum spp., Fusarium spp., and Gliocladium spp.). Pathogens killed more plants from western N.A. than from the other two regions (Pearson chi-squared test, $\chi^{2}=24.0, P<0.001$; percentage of plants from each region killed $=21 \%, 22 \%$, and $43 \%$ for Europe, central, and western N.A., respectively). We compared the average fecundity (from the first year in 2000) of western North American plants that were later killed by pathogens in the second year and those that survived. Plants killed by pathogens in 2001 produced significantly more seed capsules in 2000 than did those plants that survived pathogen attack (500 vs. 290 seed capsules for plants that died later or survived, respectively; ANOVA, $F_{1,172}=7.9, P<0.006$ ). In contrast, there was no difference in seed capsule production in 2000 between European plants that (in 2001) were killed by pathogens and those that survived to produce seeds (ANOVA, $F_{1,170}=0.08, P=0.72$ ). Thus, there was differential mortality of the most fecund western North American plants, leaving behind those individuals that produced low numbers of seed capsules. Since introduced populations in their first year of reproduction (2000) exhibited significant clinal variation in fecundity $\left(F_{1,24}=6.9, P<0.01\right)$, differential mortality before reproduction in year two likely explains why there were no clinal patterns in cumulative fecundity across both years in Spain (Fig. 5).

\section{DisCUSSION}

Exotic species often are introduced into diverse recipient communities. To succeed, these species must 
TABle 2. Extended.

\begin{tabular}{|c|c|c|c|c|c|c|c|}
\hline \multicolumn{4}{|c|}{ SP } & \multicolumn{4}{|c|}{ WA } \\
\hline df & MS & $F$ & $P$ & $\mathrm{df}$ & MS & $F$ & $P$ \\
\hline & & & & 8 & 37.1 & 4.6 & 0.0001 \\
\hline 1 & 6.8 & 3.2 & 0.085 & 1 & 65.8 & 42.7 & 0.0001 \\
\hline 2 & 22 & 5.2 & 0.01 & 2 & 26.8 & 8.8 & 0.0006 \\
\hline 2 & 0.7 & 0.2 & 0.84 & 2 & 6.5 & 2.1 & 0.13 \\
\hline 39 & 68.9 & 3.2 & 0.0001 & 44 & 66.8 & 2.8 & 0.0001 \\
\hline 260 & 146 & & & 374 & 204 & & \\
\hline
\end{tabular}

cope with different environmental conditions than what they have experienced in their native site of origin. How introduced species respond to novel environmental challenges in their new range remains unclear. We compared molecular genetic variation and the phenotypes of native and introduced St. John's wort in reciprocal common gardens in order to infer the role of rapid adaptive evolution, phenotypic plasticity, and founder effects in influencing colonization ability of a widespread exotic. While common garden experiments and molecular analysis of genetic variation are increasingly used in studies of exotics, these two approaches are seldom combined to explore the evolutionary biology of introduced species.

\section{Differences between native and introduced plants in size and fecundity}

Both plants and marine invertebrates can be larger in their introduced range than in their native range (Pritchard 1960, Crawley 1987, Fowler et al. 1996, Rees and Paynter 1997, Buckley et al. 2003, Grosholtz and Ruiz 2003). Yet, whether this is due to plasticity in response to benign recipient environments or evolutionary change brought about by unique selection pressures in the introduced range is not well understood. Pritchard (1960) was the first to provide limited evidence that increased stature in an exotic plant could be due to evolution. Based on measurements from a limited number of genotypes of St. John's wort in a single common garden he asserted "... data obtained from various populations indicate that those collected from habitats where the species is a weed are much taller than those collected from natural or semi-natural habitats."

In our study, we found no evidence to support Pritchard's (1960) assertion. Plants from central N.A. were neither universally larger nor more fecund that natives across gardens. Furthermore, western North American plants were not smaller than those from central N.A., which one might expect if increased biocontrol pressure affects allocation of resources to defense, at the expense of size or fecundity. Although we only estimated the aboveground size of plants in common gardens, in greenhouse experiments we have found no difference in shoot:root ratios between native and in- troduced genotypes (S. Elmendorf, J. L. Maron, and M. Vilà, unpublished manuscript).

In general, evidence for the evolution of increased size within introduced plant populations has been mixed. However, comparisons have mostly involved plants from a limited number of native and introduced populations grown in only one common garden (Pritchard 1960, Blossey and Nötzold 1995, Willis et al. 2000, Siemann and Rogers 2001, but see Willis and Blossey 1999) or two common gardens placed in relatively close proximity within the introduced range (Leger and Rice 2003). While these experiments have been valuable first steps in testing predictions of the EICA hypothesis, positive results from a single common garden at best only evaluate the evolutionary potential of introduced genotypes. An unambiguous demonstration of genetically based changes in phenotype requires reciprocal transplant experiments in the field. Our results serve to highlight this fact. Results from one or even two gardens were not necessarily mirrored across all gardens. For example, there were strong differences in fecundity between western North American plants and European plants in common gardens in Washington and Sweden, but not in California and Spain. Had we only established one common garden, for instance in Washington, we would have come to the erroneous conclusion that introduced plants had evolved higher fecundity than natives.

\section{Clinal variation}

Although we found no support for the EICA hypothesis, we did find latitudinally based clines in fitness in almost all gardens. This suggests that both native and introduced St. John's wort have adapted to the broad-scale abiotic conditions experienced across their current range. Since trait values were significantly different among populations even after the effects of latitude had been statistically removed, at least for native populations, it is likely that genetic drift and/or other sources of selection in addition to broad-scale climate have driven genetic differentiation. In addition to genetically fixed differences in traits, both native and introduced plants exhibited substantial phenotypic plasticity, as evidenced by the dramatic change in the slope of clines in northern vs. southern common gar- 
TABLE 3. Results from ANCOVAs testing for the effect of block (except in Spain), latitude of population origin, region of population origin, latitude $\times$ region interaction, and population nested within region on number of seed capsules (or cumulative seed capsules produced across two or three years in Spain and Washington, respectively) in California (CA), Sweden (SW), Spain (SP), and Washington (WA).

\begin{tabular}{|c|c|c|c|c|c|c|c|c|}
\hline \multirow[b]{2}{*}{ Source } & \multicolumn{4}{|c|}{$\mathrm{CA}$} & \multicolumn{4}{|c|}{ SW } \\
\hline & df & ss & $F$ & $P$ & df & ss & $F$ & $P$ \\
\hline Block & 8 & 516613 & 1.6 & 0.11 & 8 & 690764 & 1.3 & 0.25 \\
\hline Latitude & 1 & 44270556 & 18.3 & 0.002 & 1 & 457111 & 4.3 & 0.05 \\
\hline Region & 2 & 42415934 & 8.9 & 0.001 & 2 & 882002 & 4.2 & 0.03 \\
\hline Latitude $\times$ region & 2 & 3339885 & 0.7 & 0.50 & 2 & 33557 & 0.16 & 0.85 \\
\hline Population(region) & 28 & 66744214 & 6.1 & 0.0001 & 23 & 2363376 & 1.6 & 0.057 \\
\hline Error & 258 & 101528193 & & & 186 & 12277293 & & \\
\hline
\end{tabular}

dens. Although we cannot completely rule out the possibility that maternal effects influenced our results, this seems unlikely. We found no significant difference in seed mass based on region of origin, nor was there a significant relationship between latitude of origin and seed mass within or among regions (J. L. Maron, unpublished). Moreover, plants were measured after at least a year in the field, a time period sufficient for any initial maternal effect to diminish.

For natives, genetically based clinal variation in size and fecundity is not surprising. St. John's wort occurs across a large latitudinal range in Europe and latitudinal or elevational clines are often found in species that occur over steep environmental gradients (Turreson 1930, Clausen et al. 1940, Neuffer and Hurka 1986, Galen et al. 1991, Winn and Gross 1993, Jonas and Geber 1999). Clinal variation among introduced populations, however, is particularly noteworthy because it may indicate that exotics are rapidly evolving adaptations to conditions in recipient communities. Indeed, the study of clinal variation in adaptive traits has been a classic approach to understanding how organisms adapt to their environment (Clausen et al. 1940, Endler 1977). Although other studies have shown that exotic plant populations can be genetically differentiated with respect to particular traits (Jain and Martins 1979, Potvin 1986, Warwick 1990, Rice and Mack 1991, Linde et al. 2001), we know of no other study that has documented both broad-scale differentiation in adaptive traits among exotic populations based on latitude, and strong convergence between introduced and native plant populations in geographic clines for fitness.

For introduced plants, several alternative mechanisms could produce clines in traits such as those we have observed. Clines could evolve as a result of adaptive radiation from a limited number of genotypes that were introduced into North America. Alternatively, multiple introductions could result in genetically diverse populations with sufficient variation on which selection could act. In this instance, there could be genetically based adaptation among the diverse genotypes that were originally introduced or selection could simply filter out genotypes not already adapted to conditions in the recipient community. If filtering has taken place, there is no adaptive evolution. Rather, surviving plants are those that are already pre-adapted to the climatic conditions in recipient communities. Since these mechanisms have different implications regarding the importance and mode of adaptive evolution, distinguishing among them is essential if we are to fully understand the role of rapid evolution in the invasion process.

Our genetic data suggest that there have been multiple introductions of St. John's wort into North America. Plants sorted into several well-supported clades (Fig. 1), which would not be the case if there had been a massive genetic bottleneck caused by only a few founding individuals. Thus, unlike many exotic plants that show little genetic differentiation across geographic gradients (Baker 1974, Morgan and Marshall 1978, Barrett and Richardson 1986, Warwick and Black 1986, Rapson and Wilson 1988, Wang et al. 1995, Williams et al. 1995), we found substantial molecular genetic variation among introduced St. John's wort. Most of this variation was partitioned among populations; only $10 \%$ of the total variation in AFLP haplotypes was due to region of population origin (i.e., introduced vs. native). This is consistent with what has been found for other apomictic or highly selfing plants, where substantial genetic variation is often preserved among genetically differentiated populations (Widén et al. 1994, Wang et al. 1995, Bergelson et al. 1998, Miyashita et al. 1999, Auge et al. 2001).

Not only were introduced plants genetically diverse, but they were phenotypically variable as well. Introduced populations expressed as much, or in some cases more phenotypic variation in size and fecundity within any given common garden than did individuals from native populations, despite the fact that introduced populations spanned a narrower latitudinal range than did the natives.

Given that there have been multiple introductions of St. John's wort, are clines among introduced populations the result of adaptive evolution or entirely the result of plants having been introduced into areas that are climatologically similar from whence they came? Several lines of evidence suggest that St. John's wort did not universally establish at latitudes similar to their European site of origin. We found multiple cases in 
TABLE 3. Extended.

\begin{tabular}{|c|c|c|c|c|c|c|c|c|c|c|c|}
\hline \multicolumn{4}{|c|}{ SP } & \multicolumn{4}{|c|}{ WA (cumulative across first two years) } & \multicolumn{4}{|c|}{ WA (cumulative across three years) } \\
\hline df & ss & $F$ & $P$ & $\mathrm{df}$ & SS & $F$ & $P$ & $\mathrm{df}$ & SS & $F$ & $P$ \\
\hline & & & & 9 & 98751567 & 13.8 & 0.0001 & 9 & 216864022 & 12.8 & 0.0001 \\
\hline 1 & 1383719 & 3.1 & 0.08 & 1 & 15716958 & 7.6 & 0.008 & 1 & 21745730 & 4.1 & 0.05 \\
\hline 2 & 2048447 & 2.4 & 0.10 & 2 & 15673251 & 3.8 & 0.03 & 2 & 36039543 & 3.4 & 0.04 \\
\hline 2 & 531811 & 0.57 & 0.57 & 2 & 10034411 & 2.4 & 0.1 & 1 & 19934584 & 1.8 & 0.17 \\
\hline 39 & 15933275 & 2.7 & 0.0001 & 44 & 89652986 & 2.6 & 0.0001 & 44 & 232111881 & 2.8 & 0.0001 \\
\hline 250 & 37226630 & & & 406 & 319442031 & & & 404 & 749315733 & & \\
\hline
\end{tabular}
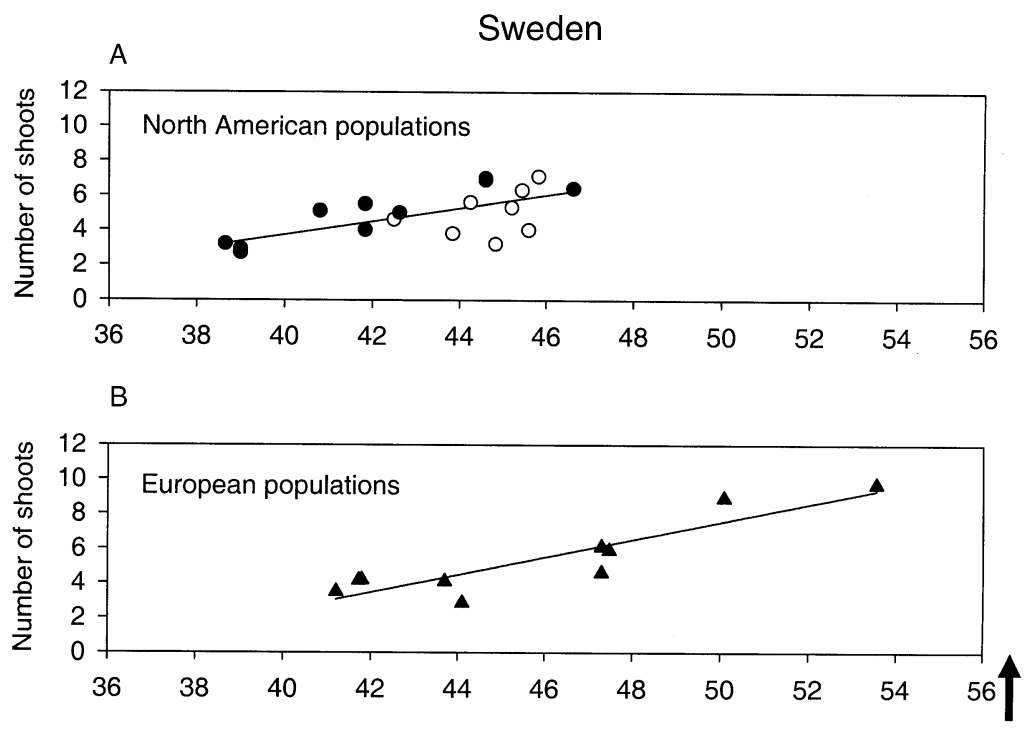

C

Washington

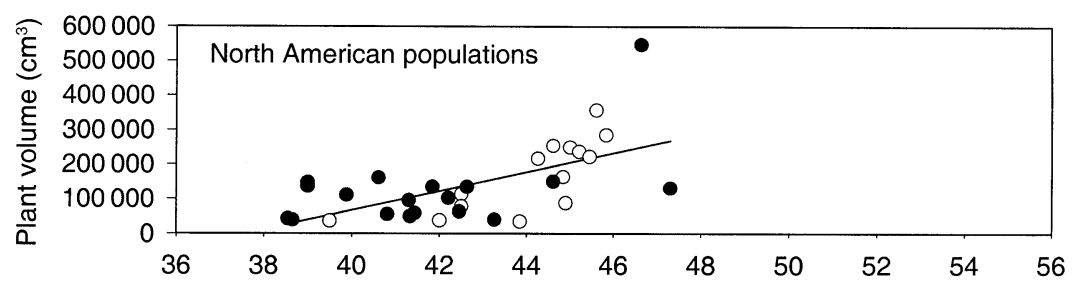

D

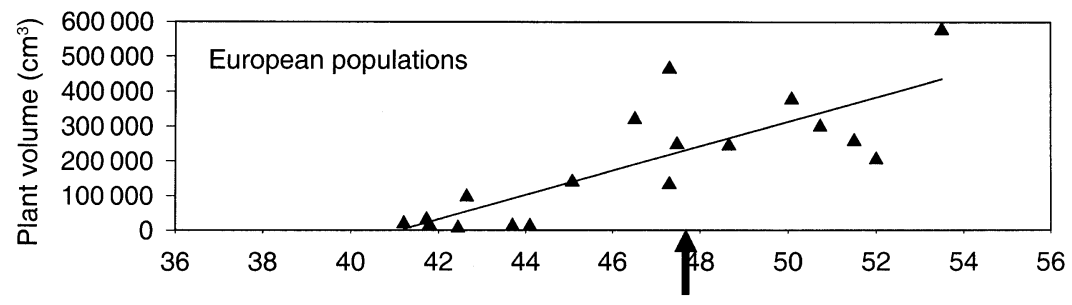

Latitude of population origin $\left({ }^{\circ} \mathrm{N}\right)$

FIG. 2. (A, B) Mean size (number of shoots) produced by 14-month-old H. perforatum plants in the Sweden common garden, and (C, D) mean size (volume) of 28-month-old plants in the Washington common garden (open circles, central North American populations; filled circles, western North American populations; triangles, European populations). Lines through points indicate significant effect of latitude. Arrows indicate the latitudes of the common gardens. 


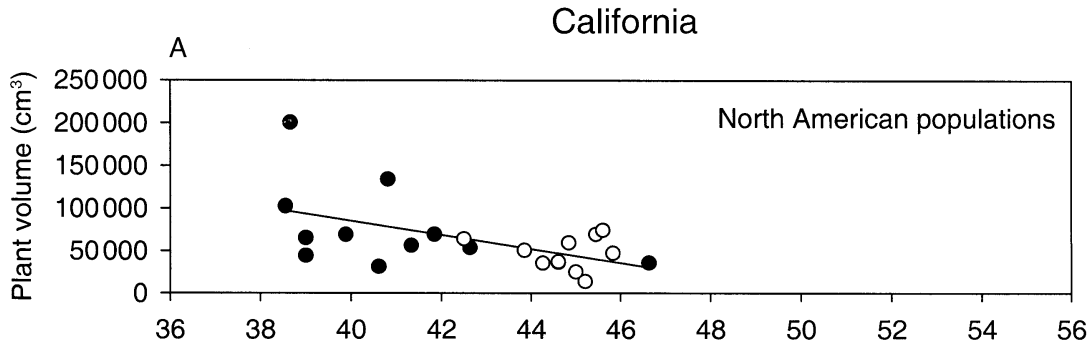

B
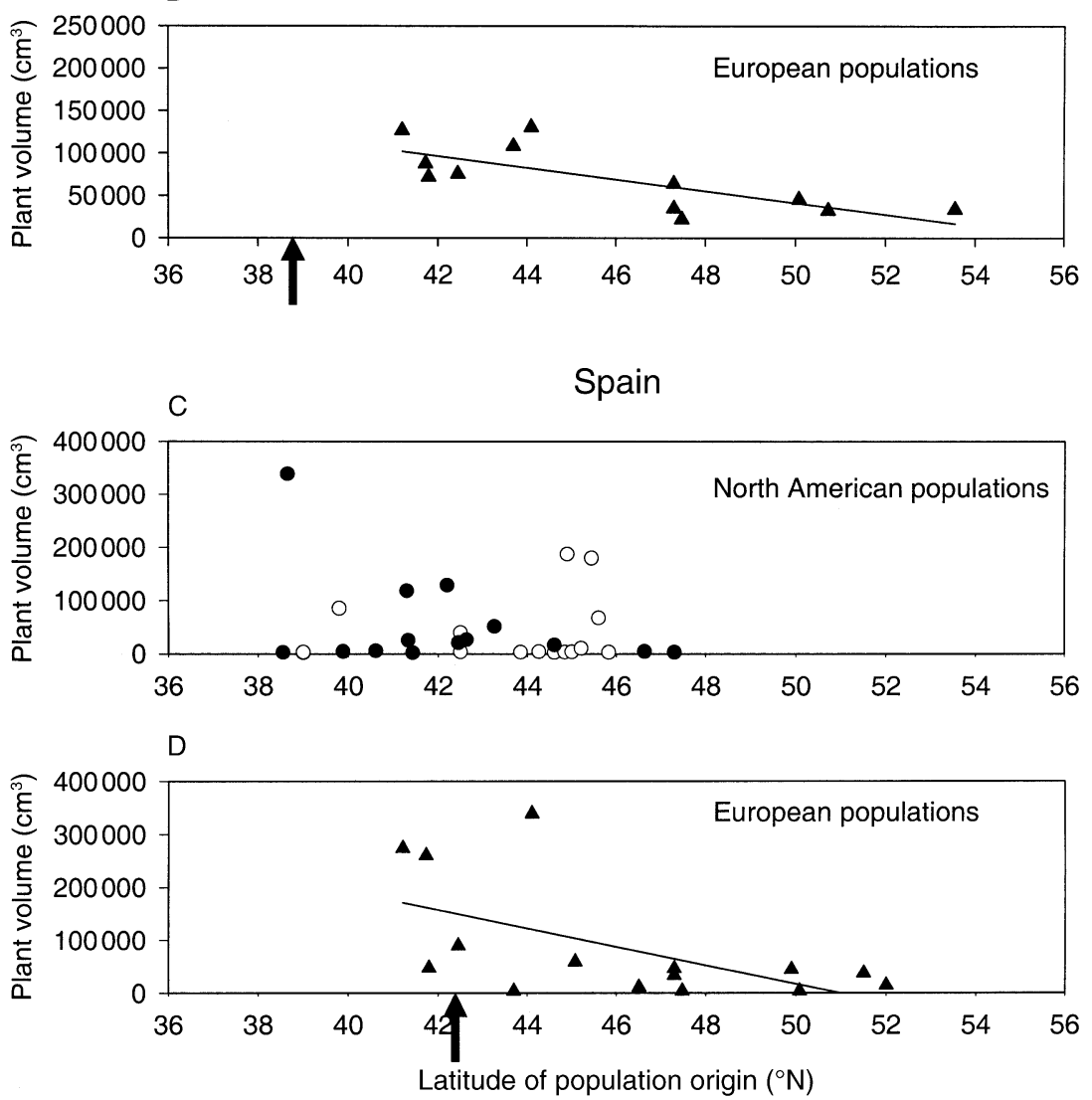

Fig. 3. (A, B) Mean size (volume) of 14-month-old H. perforatum plants in the California common garden, and (C, D) mean size (volume) of 12-month-old plants in the Spain common garden (open circles, central North American populations; filled circles, western North American populations; triangles, European populations). Lines through points indicate significant effect of latitude. Arrows indicate the latitudes of the common gardens. Note that one point from central North America is totally obscured by a western North American data point.

which particular introduced genotypes share as their closest native relative individuals originating from different latitudes than themselves (Fig. 1). For example, individuals from California populations 1 and 2, from latitudes $38.55^{\circ}$ and $38.66^{\circ} \mathrm{N}$, respectively, have as their closest European relative plants from France population 7 , which originate from latitude $44.1^{\circ} \mathrm{N}$. Plants from California populations 3 and 4 (latitudes $39^{\circ}$ and $39.25^{\circ} \mathrm{N}$, respectively) are most closely related to plants from Germany population 15 , which were from latitude $50.73^{\circ} \mathrm{N}$. Furthermore, some clades contain plants from both western and central North American populations, implying that plants from one portion of North America were founded by plants from another latitudinally distinct portion of North America, or that European genotypes were simultaneously introduced into very different recipient locales.

Patterns of leaf size variation among native and introduced plants also support the notion that plants introduced into particular latitudes did not necessarily originate from similar latitudes. For natives, leaf size is diagnostic for whether plants reside in northern or southern Europe. In native communities, plants from northern Europe have wider leaves than plants from 

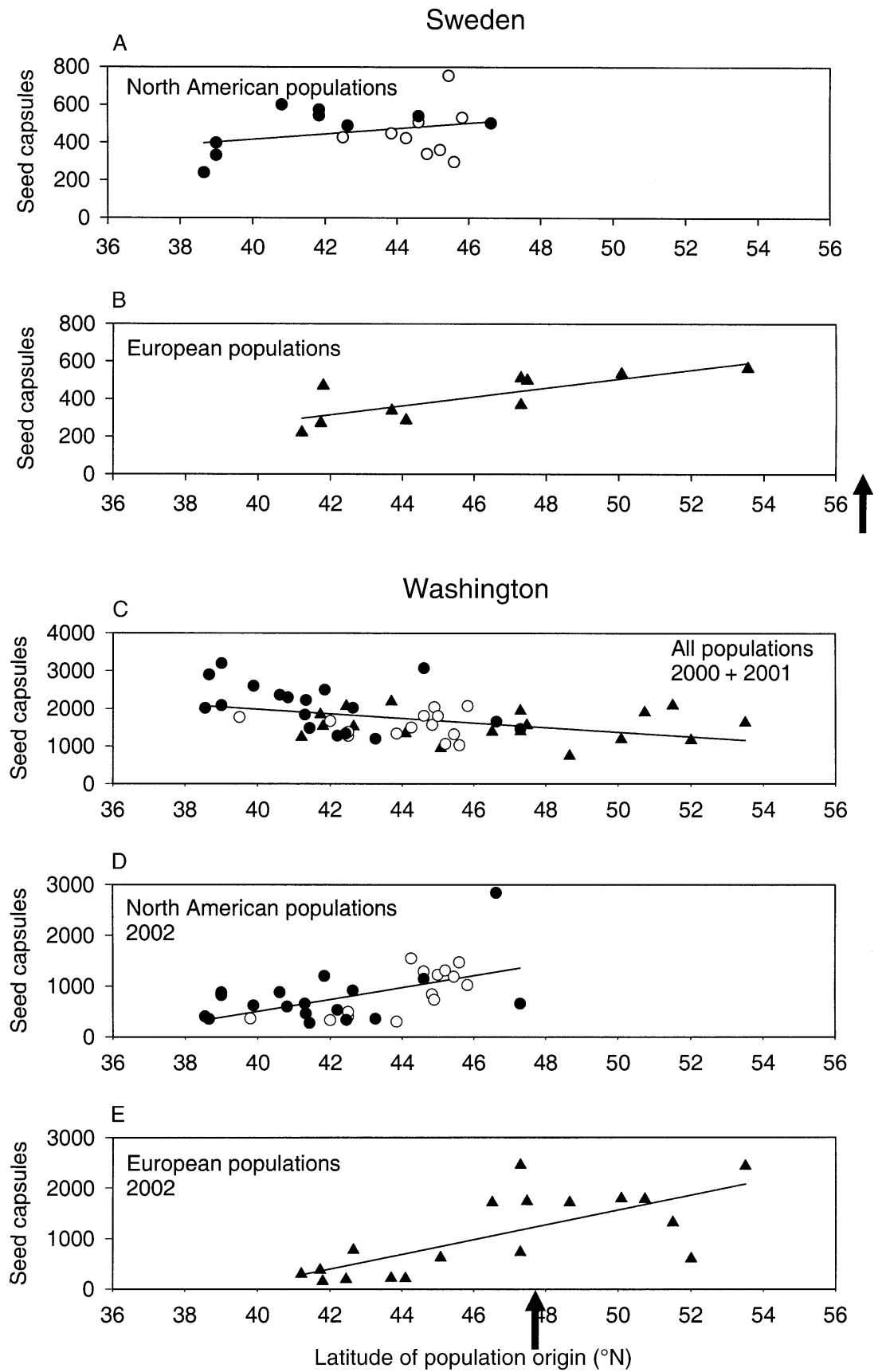

FIG. 4. (A, B) Mean number of seed capsules produced by 17-month-old H. perforatum plants in the Sweden common garden, and (C) mean cumulative number of seed capsules produced across their first and second years by plants in the Washington common garden (open circles, central North American populations; filled circles, western North American populations; triangles, European populations). (D, E) Mean number of seed capsules produced by 31-month-old plants in the Washington common garden. Lines through points indicate significant effect of latitude. Arrows indicate the latitudes of the common gardens.

the south, and in fact, northern and southern European plants are treated as different varieties (var. perforatum in the north and var. angustifolia and var. microphyllum in the south; Robson 1968). In contrast to these clear differences in leaf size among European plants (both in natural populations and in our common gardens), western North American plants did not exhibit clinal variation in leaf size in common gardens. Because this 

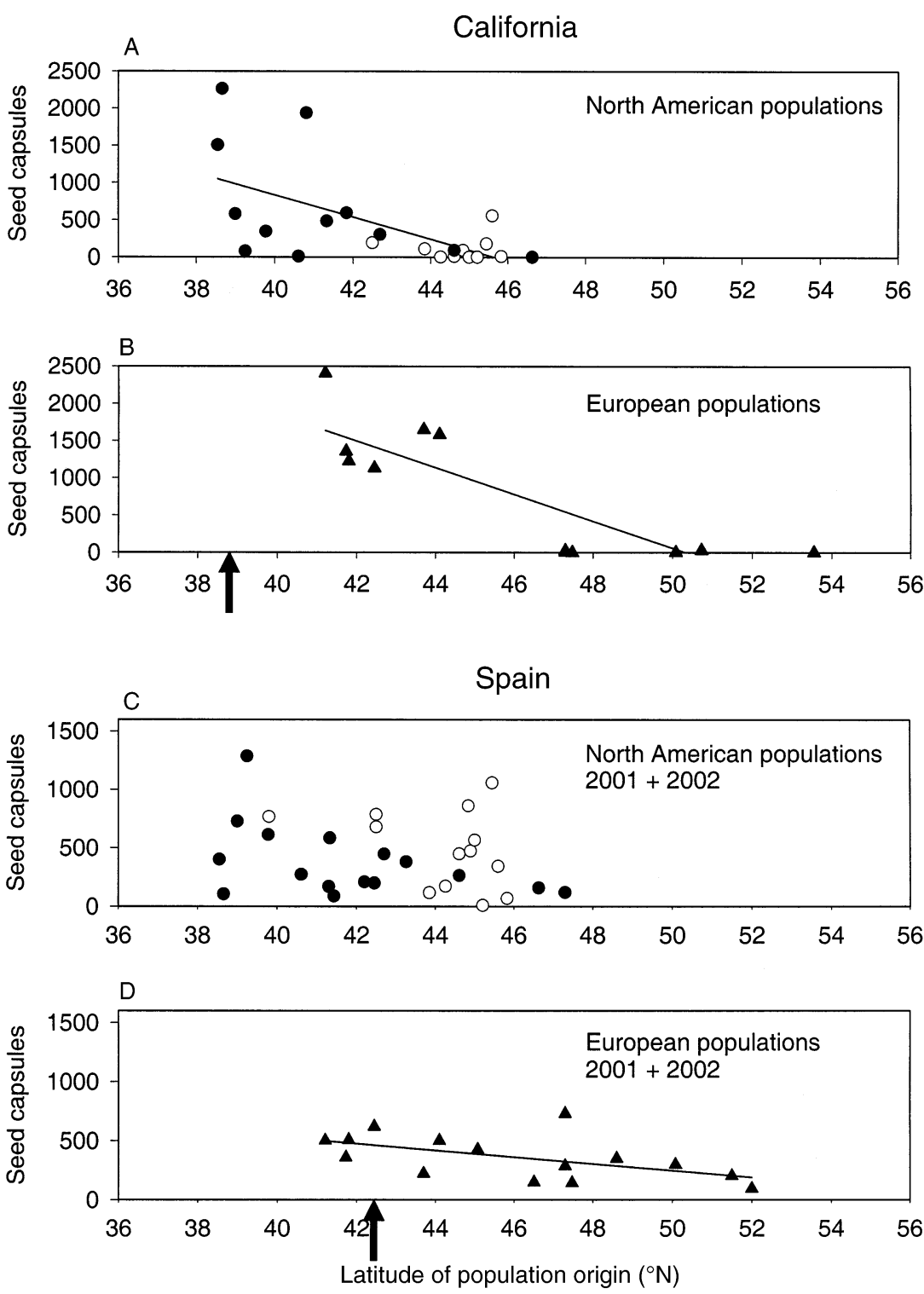

FIG. 5. (A, B) Mean number of seed capsules produced by 17-month-old H. perforatum plants in the California common garden, and (C, D) mean cumulative number of seed capsules produced across two years by plants in the Spain common garden (open circles, central North American populations; filled circles, western North American populations; triangles, European populations). Lines through points indicate significant effect of latitude. Arrows indicate the latitudes of the common gardens.

TABLE 4. Results from ANCOVA testing for the effect of block, latitude of population origin, region of population origin, latitude $\times$ region interaction, and population nested within region on leaf area in Washington (WA), and California (CA).

\begin{tabular}{|c|c|c|c|c|c|c|c|c|}
\hline \multirow[b]{2}{*}{ Source } & \multicolumn{4}{|c|}{ WA } & \multicolumn{4}{|c|}{$\mathrm{CA}$} \\
\hline & df & SS & $F$ & $P$ & df & Ss & $F$ & $P$ \\
\hline Block & 8 & 1.6 & 0.79 & 0.61 & 8 & 2.2 & 1.3 & 0.25 \\
\hline Latitude & 1 & 5.5 & 4.1 & 0.05 & 1 & 3.8 & 4.4 & 0.04 \\
\hline Region & 2 & 1.9 & 0.73 & 0.49 & 2 & 3.8 & 2.3 & 0.12 \\
\hline Latitude $\times$ region & 2 & 6.1 & 2.37 & 0.10 & 2 & 1.62 & 0.96 & 0.39 \\
\hline Population(region) & 44 & 57.3 & 5.28 & 0.001 & 28 & 23.7 & 4.26 & 0.0001 \\
\hline Error & 363 & 89.5 & & & 255 & 44.8 & & \\
\hline
\end{tabular}



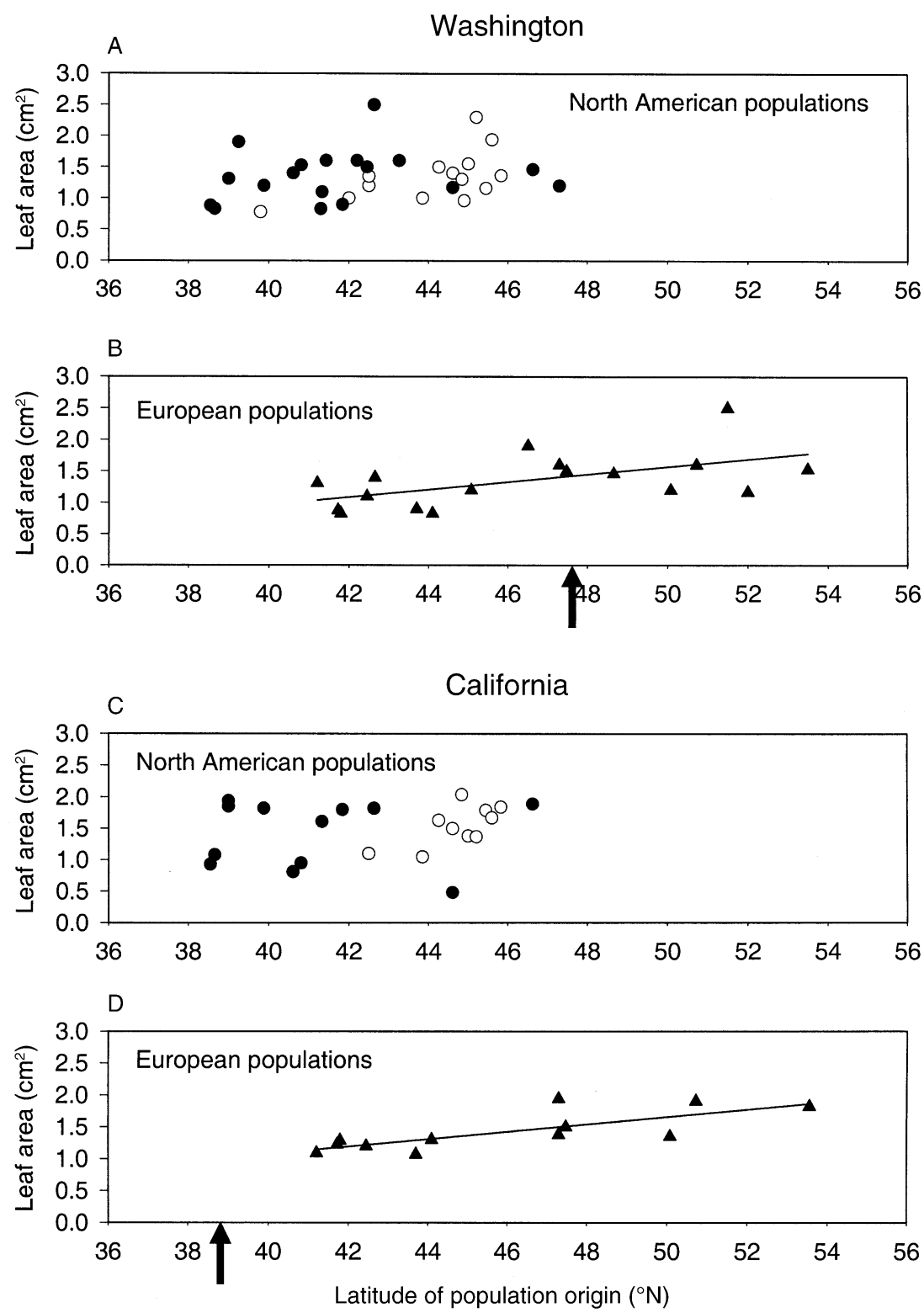

FIG. 6. (A, B) Mean leaf area of $H$. perforatum plants in the Washington common garden, and (C, D) mean leaf area of plants in the California common garden (open circles, central North American populations; solid circles, western North American populations; triangles, European populations). Lines through points indicate significant effect of latitude. Arrows indicate the latitudes of the common gardens.

TABLE 5. Percentage of total phenotypic variation in size or fecundity partitioned among European and western North American (N.A.) populations in common gardens in California (CA), Sweden (SW), and Washington (WA).

\begin{tabular}{lccc}
\hline \hline Population & CA & SW & WA \\
\hline Size & & & \\
$\quad$ Native & 51.5 & 52.8 & 39.3 \\
$\quad$ Western N.A. & 48.5 & 47.2 & 60.7 \\
$\quad$ Fecundity & & & \\
$\quad$ Native & 53.5 & 29.6 & 40.6 \\
$\quad$ Western N.A. & 46.5 & 70.4 & 59.4 \\
\hline
\end{tabular}

trait appears not to have yet responded to conditions in the introduced range, leaf size may be a reasonable proxy for the latitude that western North American plants originated from in Europe. Since some largeleaved populations were found at southern latitudes in western N.A., it appears that southern latitude populations in western N.A. likely originated from more northern latitudes in Europe.

Taken together, genetic and common garden data suggest the following scenario. Multiple introductions of St. John's wort into North America provided sufficient phenotypic (and underlying genetic) variation on 
which selection could act. Some introduced genotypes undoubtedly originated from regions that shared a similar abiotic regime as that experienced in their recipient community, and therefore were pre-adapted to particular conditions experienced in North America. However, given the patterns discussed above, it also seems likely that many populations were founded by individuals that were not pre-adapted to the latitude (and hence climatic conditions) of introduction. Plants within these populations appear to be evolving in response to current conditions experienced in their recipient community. Since the earliest arriving genotypes of St. John's wort have only been in North America for $\sim 150$ years (and likely less time in California), or perhaps 12-15 plant generations, this evolutionary adaptation is occurring quite rapidly.

\section{Concluding remarks}

Exotic plant introductions represent a grand, if unfortunate, experiment in evolutionary ecology. This was first recognized over 35 years ago by evolutionary biologists who were among the first to explore the evolutionary potential of introduced plants (Baker and Stebbins 1965, Baker 1974). However, this evolutionary perspective has mostly been ignored in the burgeoning ecological literature on invasion biology (Parker et al. 2003).

Our results generally support the contention that introduced plants can undergo contemporary evolution (Bone and Farres 2001), and that adaptive evolution may be one of several key mechanisms enabling exotics to succeed in recipient communities. Hopefully, increasing awareness of the importance of contemporary evolution in the ecology of invasions will catalyze a greater fusion of ecological and evolutionary perspectives in future studies of exotic plants (Thompson 1998, Bone and Farres 2001, Lee 2002). Melding of these often disparate approaches offers tremendous potential to crack the mystery of why exotic species are able to attain such staggeringly high densities in recipient communities, while their native counterparts virtually never do.

\section{ACKNOWLEDGMENTS}

This work benefited from early discussions with Richard Root and Doug Schemske. We thank D. Ewing and the rest of the staff in the Botany greenhouse at the University of Washington for their help in propagating plants. T. Bradshaw graciously allowed us to work in his laboratory, and B. Frewen, J. Pijoan, and D. Grosenbacher ably performed AFLP analyses. Paul Spruell helped with analyzing molecular data. Thanks to B. Clifton, D. Grosenbacher, J. Jones, T. Hirsch, T. Huettner, J. Pijoan, and M. Wolven for helping establish and maintain the Washington common garden and to K. Parker for allowing the use of her land in Washington for our common garden. The Napa Land Trust permitted us to establish our garden on their property in California, and L. Amsberry, J. Calizo, and S. Harrison helped with logistics and/or fieldwork in establishing this common garden. In Spain, we thank P. Matas from the Universitat de Barcelona greenhouse for assistance in propagating plants and J. Serra and the staff in Mas Badia (IRTA), as well as I. Gimeno, L. Marco, and F. Debicki for their assistance maintaining the common garden in Spain. In Sweden, we thank the Folkesson family for kindly allowing us to establish our experiment on their land and for the use of their machinery. S. Lagergren, A. Bommarco, and S. Öberg provided help in the field. The manuscript was improved by comments from L. Amsberry, J. Brodie, E. Crone, J. Robertson, and J. Williams. We are tremendously grateful to A. Angert, D. Ayers, J. Combs, U. Gamper, S. Gardner, D. Greiling, F. Grevstad, J. Hess, R. Keller, P. Kittelson, E. Knapp, E. Ogheri, P. Pysek, A. Sears, R. Sobhian, A. Stanley, J. Taft, E. Weber, A. Weis, and A. Wolf for collecting $H$. perforatum seeds for us. This work was supported by grants to J. L. Maron from the University of Washington Royalty Research Fund and from NSF grant DEB-0296175 and to M. Vilà by a grant from DURSI (Generalitat de Catalunya).

\section{Literature Cited}

Arnholdt-Schmitt, B. 2000. RAPD analysis: a method to investigate aspects of the reproductive biology of Hypericum perforatum L. Theoretical Applications in Genetics 100: 906-911.

Auge, H., B. Neuffer, F. Erlinghagen, R. Grupe, and R. Brandl. 2001. Demographic and random amplified polymorphic DNA analyses reveal high levels of genetic diversity in a clonal violet. Molecular Ecology 10:18111819.

Baker, H. G. 1974. The evolution of weeds. Annual Review of Ecology and Systematics 5:1-24.

Baker, H. G., and G. L. Stebbins, editors. 1965. The genetics of colonizing species. Academic Press, New York, New York, USA.

Barrett, S. C. H., and B. J. Richardson. 1986. Genetic attributes of invading species. Pages 21-33 in R. H. Groves and J. J. Burdon, editors. Ecology of biological invasions. Cambridge University Press, Cambridge, UK.

Bergelson, J., E. Stahl, S. Dudek, and M. Kreitman. 1998. Genetic variation within and among populations of Arabidopsis thaliana. Genetics 148:1311-1323.

Blossey, B., and R. Nötzold. 1995. Evolution of increased competitive ability in invasive nonindigenous plants: a hypothesis. Journal of Ecology 83:887-889.

Bone, E., and A. Farres. 2001. Trends and rates of microevolution in plants. Genetica 112-113:165-182.

Brown, A. H. D., and D. R. Marshall. 1981. Evolutionary changes accompanying colonization in plants. Pages 7398 in G. G. E. Scudder and J. L. Reveal, editors. Evolution today. Proceedings of the Second International Congress of Systematics and Evolutionary Biology, Hunt Institute of Botanical Documentation, Carnegie-Mellon University, Pittsburgh, Pennsylvania, USA.

Buckley, Y. M., P. Downey, S. V. Fowler, R. Hill, J. Memmot, H. Norambuena, M. Pitcairn, R. Shaw, A. W. Sheppard, C. Winks, R. Wittenberg, and M. Reese. 2003. Are invasives bigger? A global study of seed size variation in two invasive shrubs. Ecology 84:1434-1440.

Campbell, M. H., and E. S. Delfosse. 1984. The biology of Australian weeds. 13. Hypericum perforatum. Journal of Australian Institute of Agricultural Science 50:63-73.

Clausen, J., D. D. Keck, and W. M. Hiesey. 1940. Experimental studies on the nature of species. I. The effects of varied environments on North American plants. Carnegie Institute of Washington Publication Number 520, Washington, D.C., USA.

Crawley, M. J. 1987. What makes a community invasible? Pages 429-453 in A. J. Gray, M. J. Crawley, and P. J. Edwards, editors. Colonization, succession and stability. Blackwell Scientific, Oxford, UK.

Elton, C. S. 1958. The ecology of invasions. Methuen, London, UK. 
Endler, J. A. 1977. Geographic variation, speciation and clines. Monographs in Population Biology. Princeton University Press, Princeton, New Jersey, USA.

Felsenstein, J. 1985. Confidence limits on phylogenies: an approach using the bootstrap. Evolution 39:783-791.

Fields, P. G., J. T. Arnason, and B. J. R. Philogene. 1988. Distribution of Chrysolina spp. (Coleoptera: Crysomelidae) in eastern Ontario, 18 years after their initial release. Canadian Entomologist 120:937-938.

Fowler, S. V., H. M. Harman, J. Memmott, Q. Paynter, R. Shaw, A. W. Sheppard, and P. Syrett. 1996. Comparing the population dynamics of broom, Cytisus scoparius, as a native plant in the United Kingdom and France and as an invasive alien weed in Australia and New Zealand. Pages 19-26 in V. C. Moran and J. H. Hoffmann, editors. Proceedings of the IX International Symposium on Biological Control of Weeds. University of Cape Town, Stellenbosch, South Africa.

Galen, C., J. S. Shore, and H. Deyoe. 1991. Ecotypic divergence in alpine Polemonium viscosum: genetic structure, quantitative variation, and local adaptation. Evolution 45 : $1218-1228$.

Gillett, J. B. 1962. Pest pressure, an underestimated factor in evolution. Pages 37-46 in Taxonomy and geography. Systematics Association Publication Number 4.

Grosholz, E. D., and G. M. Ruiz. 2003. Biological invasions drive size increases in marine and estuarine invertebrates. Ecology Letters 6:705-710.

Harris, P., and M. Maw. 1984. Hypericum perforatum L., St John's-wort (Hypericaceae). Pages 171-177 in J. S. Kelleher and M. A. Hulme, editors. Biological control programmes against insects and weeds in Canada 1969-1980. Commonwealth Agricultural Bureaux, Slough, UK.

Hoebeke, E. R. 1993. Establishment of Urophora quadrifasciata (Diptera: Tephritidae) and Chrysolina quadrigemina (Coleoptera: Chrysomelidae) in portions of eastern United States. Entomological News 104:143-152.

Holloway, J. K. 1957. Weed control by an insect. Scientific American 197:56-62.

Holloway, J. K., and C. B. Huffaker. 1951. The role of Chrysolina gemellata in the biological control of Klamath Weed. Journal of Economic Entomology 44:244-247.

Huey, R. B., G. W. Gilchrist, M. L. Carlson, D. Berrigan, and L. Serra. 2000. Rapid evolution of a geographic cline in size in an introduced fly. Science 287:308-309.

Huffaker, C. B., and J. K. Holloway. 1949. Changes in range plant population structure associated with feeding of imported enemies of Klamath Weed (Hypericum perforatum L.). Ecology 30:167-175.

Jain, S. K., and P. S. Martins. 1979. Ecological genetics of the colonizing ability of rose clover (Trifolium hirtum All.). American Journal of Botany 66:361-366.

Jonas, C. S., and M. A. Geber. 1999. Variation among populations of Clarkia unguiculata (Onagraceae) along altitudinal and latitudinal gradients. American Journal of Botany 86:333-343.

Julien, M. H., and M. W. Griffiths. 1998. Biological control of weeds. A world catalogue of agents and their target weeds. Fourth edition. CABI Publishing, Wallingford, UK.

Kaufman, S. R., and P. E. Smouse. 2001. Comparing indigenous and introduced populations of Melaleuca quinquenervia (Cav.) Blake: response of seedlings to water and $\mathrm{pH}$ levels. Oecologia 127:487-494.

Lacey, E. P. 1988. Latitudinal variation in reproductive timing of a short-lived monocarp, Daucus carota (Apiaceae). Ecology 69:220-242.

Lee, C. E. 2002. Evolutionary genetics of invasive species. Trends in Ecology and Evolution 17:386-391.

Leger, E. A., and K. J. Rice. 2003. Invasive California poppies (Eschscholzia californica Cham.) grow larger than na- tive individuals under reduced competition. Ecology Letters 6:257-264.

Linde, N., S. Diel, and B. Neuffer. 2001. Flowering ecotypes of Capsella bursa-pastoris (L.) Medik. (Brassicaceae) analysed by a cosegregation of phenotypic characters (QTL) and molecular markers. Annals of Botany 87:91-99.

Losos, J. B., K. B. Warheit, and T. W. Schoener. 1997. Adaptive differentiation following experimental island colonization in Anolis lizards. Nature 387:70-73.

Marshall, D. R., and S. K. Jain. 1968. Phenotypic plasticity of Avena fatua and A. barbata. American Naturalist 102: 457-467.

Miyashita, N. T., A. Kawabe, and H. Innan. 1999. DNA variation in the wild plant Arabidopsis thaliana revealed by amplified fragment length polymorphism analysis. Genetics 152:1723-1731.

Morgan, G. F., and D. R. Marshall. 1978. Allozyme uniformity within and variation between races of the colonizing species Xanthium strumarium L. (Noogoora burr). Australian Journal of Biological Sciences 31:284-292.

Mueller, U. G., and L. L. Wolfenbarger. 1999. AFLP genotyping and fingerprinting. Trends in Ecology and Evolution 14:389-394.

Nei, M., and W. H. Li. 1979. Mathematical models for studying genetic variation in terms of restriction endonucleases. Proceedings of the National Academy of Sciences USA 76: 5269-5273.

Neuffer, B. 1990. Ecotype differentiation in Capsella. Vegetatio 89:165-171.

Neuffer, B., and H. Hurka. 1986. Variation in growth form parameters in Capsella (Cruciferae). Plant Systematics and Evolution 153:265-279.

Neuffer, B., and H. Hurka. 1999. Colonization history and introduction dynamics of Capsella bursa-pastoris (Brassicaceae) in North America: isozymes and quantitative traits. Molecular Ecology 8:1667-1681.

Novak, S. J., and R. N. Mack. 2001. Tracing plant introduction and spread: genetic evidence from Bromus tectorum (Cheatgrass). BioScience 51:114-122.

Parker, I. M., J. Rodriguez, and M. E. Loik. 2003. An evolutionary approach to understanding the biology of invasions: local adaptation and general-purpose genotypes in the weed Verbascum thapsus. Conservation Biology 17:115.

Potvin, C. 1986. Biomass allocation and phenological difference among southern and northern populations of the $\mathrm{C}_{4}$ grass Echinochloa crus-galli. Journal of Ecology 74:915923.

Pritchard, T. 1960. Race formation in weedy species with special reference to Euphorbia cyparissias L. and Hypericum perforatum L. Pages 61-66 in J. L. Harper, editor. The biology of weeds: a symposium of the British Ecological Society. Blackwell Scientific, Oxford, UK.

Rapson, G. L., and J. B. Wilson. 1988. Non-adaptation in Agrostis capillaris L. (Poaceae). Functional Ecology 2: 479-490.

Rees, M., and Q. Paynter. 1997. Biological control of Scotch broom: modeling the determinants of abundance and the potential impact of introduced insect herbivores. Journal of Applied Ecology 34:1203-1221.

Reznick, D. N., F. H. Shaw, R. H. Rodd, and R. G. Shaw. 1997. Evaluation of the rate of evolution in natural populations of guppies (Poecilia reticulata). Science 275: 1934-1937.

Rice, K. J., and R. N. Mack. 1991. Ecological genetics of Bromus tectorum. III. The demography of reciprocally sown populations. Oecologia 88:91-101.

Robson, N. K. B. 1968. Guttiferales. CIX. Guttifereae (Clusiaceae). Pages 261-269 in Flora Europaea 2. Cambridge University Press, Cambridge, UK. 
Samson, A. W., and K. W. Parker. 1930. St. Johns-wort on rangelands of California. California Agriculture Experiment Station Bulletin 503, Berkeley, California, USA.

SAS. 2001. PROC GLM in SAS, version 8.2. SAS Institute, Cary, North Carolina, USA.

Schneider, S., D. Roessli, and L. Excoffier. 2000. ARLEQUIN: a software for population genetic data. Genetics and Biometry Laboratory, University of Geneva, Geneva, Switzerland.

Sexton, J. P., J. K. McKay, and A. Sala. 2002. Plasticity and genetic diversity may allow saltcedar to invade cold climates in North America. Ecological Applications 12:16521660.

Siemann, E., and W. E. Rogers. 2001. Genetic differences in growth of an invasive tree species. Ecology Letters 4:514518.

Stockwell, C. A., A. P. Hendry, and M. T. Kinnison. 2003. Contemporary evolution meets conservation biology. Trends in Ecology and Evolution 18:94-101.

Sultan, W. E., and F. A. Bazzaz. 1993. Phenotypic plasticity of Polygonum persicaria. I. Diversity and uniformity in genotypic norms of reaction to light. Evolution 47:10091031.

Swofford, D. L. 1998. PAUP* 4.0: phylogenetic analysis using parsimony. Smithsonian Institution, Washington, D.C., USA.

Thébaud, C., and D. Simberloff. 2001. Are plants really larger in their introduced ranges? American Naturalist 157 231-236.

Thompson, J. N. 1998. Rapid evolution as an ecological process. Trends in Ecology and Evolution 13:329-332.

Turreson, G. 1930. The selective effect of climate upon the plant species. Hereditas 14:99-152.

Vos, P., R. Hogers, M. Bleeker, M. Reijans, T. van de Lee, M. Hornes, A. Frijters, J. Pot, J. Peleman, M. Kuiper, and M. Zabeau. 1995. AFLP: a new technique for DNA fingerprinting. Nucleic Acids Research 23:4407-4414.

Voss, E. G. 1985. Michigan flora. Part II. Dicots (Saururaceae-Cornaceae). Cranbrook Institute of Science, Cranbrook, Michigan, USA.
Wang, R.-L., J. F. Wendel, and J. H. Dekker. 1995. Weedy adaptation in Setaria spp. II. Genetic diversity and population genetic structure in $S$. glauca, S. geniculata, and $S$. faberii (Poaceae). American Journal of Botany 82:10311039

Warwick, S. I. 1990. Allozyme and life history variation in five northward colonizing North American weed species. Plant Systematics and Evolution 169:41-54.

Warwick, S. I., and L. D. Black. 1986. Genecological variation in recently established populations of Abutilon theophrasti. Canadian Journal of Botany 64:1632-1643.

Weber, E., and B. Schmid. 1998. Latitudinal population differentiation in two species of Solidago (Asteraceae) introduced into Europe. American Journal of Botany 85:11101121 .

Widén, B., N. Cronberg, and M. Widén. 1994. Genotypic diversity, molecular markers and spatial distribution of genets in clonal plants, a literature survey. Folia Geobotanica et Phytotaxonomica 29:245-263.

Williams, D. G., R. N. Mack, and R. Black. 1995. Ecophysiology of introduced Pennisteum setaceum on Hawaii: the role of phenotypic plasticity. Ecology 76:1569-1580.

Willis, A. J., and B. Blossey. 1999. Benign environments do not explain the increased vigour of non-indigenous plants: a cross-continental transplant experiment. Biocontrol Science and Technology 9:567-577.

Willis, A. J., J. Memmott, and R. I. Forrester. 2000. Is there evidence for the post-invasion evolution of increased size among invasive plant species? Ecology Letters 3:275-283.

Winn, A. A., and K. L. Gross. 1993. Latitudinal variation in seed weight and flower number in Prunella vulgaris. Oecologia 93:55-62.

Xu, R. Q., N. Tomooka, and D. A. Vaughan. 2000. AFLP markers for characterizing the azuki bean complex. Crop Science 40:808-815.

Yom-Tov, Y., S. Yom-Tov, and H. Moller. 1999. Competition, coexistence, and adaptation amongst rodent invaders to $\mathrm{Pa}$ cific and New Zealand islands. Journal of Biogeography 26:947-958.

\section{APPENDIX}

A table of the locations of seed source populations is available at ESA's Electronic Data Archive: Ecological Archives M074-005-A1. 